\title{
The Distribution of Residual Controls and Risk Sharing: A Case Study of Farmland Transfer in China
}

\author{
Hongyun Han ${ }^{1}$ and Hanning $\mathrm{Li}^{2, *}$ (D) \\ 1 School of Public Affairs, Zhejiang University, Qizhen Building, 866 Yuhangtang Road, \\ Hangzhou 310058, China; hongyunhan@zju.edu.cn \\ 2 School of Management, Zhejiang University, Qizhen Building, 866 Yuhangtang Road, \\ Hangzhou 310058, China \\ * Correspondence: 11320050@zju.edu.cn; Tel.: +86-136-1571-2946
}

Received: 26 April 2018; Accepted: 12 June 2018; Published: 15 June 2018

\begin{abstract}
Structuring contracts to share interest and risk is the central premise of farmland transfer, yet the contract framework and its determinants have rarely been empirically tested based on micro-level data. In this study, we aim to examine factors underlying the balanced distribution of residual controls and risk sharing on contract framework by using field surveyed data of 353 individual farmland transfer contracts. Our evidence shows that the policy of farmland property rights registration has a significant effect on the contract framework and supports the implication of enforcement costs exerted by the effects of the scale ratio and the contract form, contract duration, conversion way, and long-lived assets input. Although our findings fail to support the typical implication of risk sharing as an explanation of contract framework of farmland transfer, given the symmetric positions of two contracted parties of rural farmer households, it is proved that right confirmation and contract duration are two important factors underlying contract options.
\end{abstract}

Keywords: farmland transfer; contract framework; risk sharing; China

\section{Introduction}

A market economy is the contract network between individuals and organized groups [1]. As the economics of contracts has emerged as the requirement of the methodological innovation in economic research, there exists a revolution of contract economics from commodity analysis to transaction analysis [2]. Transaction cost, uncertainty, and risk-sharing emerge to be the core of economic research [3]. Taking into consideration the effect of economic incentives and the attitude towards risks of the contracting parties, the relationship of risk-sharing and contract design is the core issue of modern contract research [4]. The idea of risk sharing in explaining the share contract has deep roots in contract theory [5]. While the existing studies on the determinants of contract arrangement are vast and insightful [6], there is little empirical evidence supporting risk sharing as a significant determinant of contract arrangements in agriculture, and little analysis has been made on the underlying reason of the inapplicability of risk sharing theory [7].

Since the mid-late 1990s, the contract structure of the agricultural shareholding in a cooperative system [8], the development of agricultural industrialization $[9,10]$ and the choice of organizational patterns $[11,12]$ have been the key issues of transaction cost economics. Due to the underdevelopment of formal agricultural finance and insurance in China, the contracts of production, processing, and sale with firms are adopted by farmers to avoid agricultural contract risks [13]. The balanced risk allocation has been the main topic of contract analysis [14]. The symmetric distribution of the residual rights and risk sharing is one of the important principles of contract design and choice [15]. However, the exploration of the distribution of residual controls and risk sharing has not attracted enough 
attention due to the difficulty of the quantitative measurement of risk, and so far, studies on risk allocation in China mostly remain on the theoretical analysis of risk identification, causes, and control system [16]. The design of farmland transfer system in China is faced with a trade-off between the protection of farmer's rights and the risk allocation [17]. The lagged research on the economics of contracts hinders the sound development of the market system in China.

The initial development of the modern contract theory began in the research on share tenancy. Faced with transaction costs and information asymmetry [18], the paradigm of complete information and perfect competition in neoclassical economics cannot explain the efficiency of the market. Uncertainty had been recognized by Edgeworth in the period of neoclassical contract economics [19], including uncertainty from production and consumption, the natural circumstance of contract design and enforcement, economic fluctuation, and management of organization [20]. The risk is the measurable uncertainty, emerging from the incapability of contracts to regulate all the contingencies [21]. Uncertainty and risk-sharing are important factors affecting the arrangement of the contract, and they are also the immediate causes of the incompleteness of the contract [22]. Agriculture has long been an experimental field of contracts of wages, rents, and prices [23]. In particular, contract arrangement of agricultural tenancy has continuously fascinating economists and will continue to do so until its main riddles are satisfactorily resolved [24], such as the difficulty in the accurate measurement of transaction costs [25], the lack of interactional study with production costs [26], and unbalanced risk allocation [23]. Further study of incentive contract design with the consideration of risk-adverse principal and agent is needed in contract analysis.

A contract is designed to completely or partially transfer the property rights, in order to unite the production of owners with different resources. Due to the incompleteness of the contract, however, property rights cannot be simply defined as ownership rights or decision rights. More precisely, the contract should be regarded as the arrangement of residual control rights under the condition of information incompleteness [27]. It is believed that risk sharing determines the structure of the contract and the choice of the contract [28]. While considerable theoretical efforts have been made by economists in understanding agricultural contracts, few empirical studies have been undertaken to examine the factors underlying the distribution of residual controls and risk sharing [29]. The hypothesis of risk-neutral principals and agents of Coase and Williamson has been supported by a growing number of studies [24], which have inferred the limitations in the rationale of the risk-sharing model under the traditional principal-agent paradigm with risk-neutral principals and risk-adverse agent. Ignoring the principal's moral hazard derived from measuring and dividing the input, the one-sided model of merely assuming the agent's margin for shirking constrains the analysis of contracts [30].

Using detailed surveyed data on 353 individual contracts of farmland transfer from Chengde city, Hebei province in China, the main contribution of this article is to examine the factors underlying allocation of residual controls and risks, and further explore the effect of the farmland property rights on the contract framework under the farmland system in China. This paper proceeds as follows. We begin by reviewing the literature about contract arrangement of farmland transfer in Section 2 . Section 3 presents the surveyed data and summary statistics, followed by the discrete choice model to explain the choice between fixed-rent and share contracts. Section 4 presents the empirical results and corresponding explanation. The conclusions and policy implication are presented in Section 4.

\section{The Model and Data}

\subsection{The Model}

\subsubsection{The Separation of Residual Control and Residual Rights}

Property rights theory refines this thinking by taking the view that the owner of a nonhuman asset possesses residual control rights over that asset, and that there is an optimal allocation of such residual control rights [31]. According to Bromley, "ownership is not absolute control. That is, ownership is the right to possess, to use, to manage, to benefit, to be secure, and to alienate. Control, therefore, is the 
right to disregard the interests of others in the exercise of the above dimensions of ownership" [32] (p. 159). Grossman and Hart (1995) have deepened Bromley's work, they define the firm as "being composed of the assets that it owns" and ownership as "the purchase of these residual rights of control" (p. 288). The ownership is virtually defined as the power to exercise control. Grossman and Hart (1986) provided a more refined classification of contract rights as specific rights and residual rights. The former refers to the rights explicitly regulated in the contract, and the latter refers to those not written in the contract regulating the property usufruct [31]. It is a thorough revolution of the economics of contracts to the general equilibrium paradigm in neoclassical economics by incorporating the information, institution and property rights into economic research [33].

As an institutional arrangement of resource allocation, the contract regulates the specific distribution of rights and obligations between the contracting parties [34]. The principal-agent theory claims that a complete incentive contract arrangement is designed to induce the agent's efforts against the constraint of participation and incentive-compatibility. Thus, the maximization of the principal's utility can be achieved under the condition of asymmetric information and interest conflicts. An incentive compatible contract of benefit allocation could be regarded as the arrangement of residual control rights under the condition of information incompleteness [35]. Because of the incompleteness resulted from bounded rationality and asymmetric information, residual rights of control are important. Hart (1995) precisely points out that "governance structure does matter if agency problems are present and contracts are incomplete" (p. 679).

Residual control rights and residual claim do not have to be bundled together. In practical profit-sharing agreements, some party can be regulated as the residual claimant for an asset, but not necessarily as the one holding residual control rights [36]. Here we employ Hart's definition,

"Governance structure can be seen as a mechanism for making decisions that have not been specified in the initial contract. More precisely, governance structure allocates residual rights of control over the firm's non-human assets; that is, the right to decide how these assets should be used, given that a usage has not been specified in an initial contract."-Oliver Hart, Corporate Governance: Some Theory and Implications, The Economic Journal, 105, pp. 678-689.

Why should residual control rights and residual claim often go together? [36] The principal-agent problem induced by asymmetric information and conflicts of interest is the biggest challenge in the design of incentive mechanisms [37]. The principal needs to design the incentive mechanism to limit an agent's behavior of adverse selection and moral hazard [38]. By satisfying the participation constraint and the incentive-compatibility constraint of the agent, the principal-agent mechanism is a balanced arrangement of incentive and risk allocation [39] to achieve the optimal allocation of resources [40].

A contract is designed to regulate the uncertain future terms in order to avoid or share risks [41]. Theoretical research on contracts has been propelled by a series of works by Cheung. In The Theory of Share Tenancy, Cheung initially distinguished the contract choice of the fixed-rent contract, share contract and wage contract in effects of risk-sharing and economic incentives [5]. In his article Transaction Costs, Risk Aversion, and the Choice of Contractual Arrangements, Cheung further concluded that the choice of contracts was jointly determined by transaction costs, natural risks and physical attributes of the input and output [42].

The essential difference between the contract arrangements comes from the property rights allocation [43]. The arrangement of property rights is to balance the allocation of the residual claim rights and the residual control rights among stakeholders [44]. Between the dominant contract frameworks of fixed-rent and share contract, the argument is mainly generated from two strands of literature which have engaged to furnish plausible explanations: (1) risk-sharing models, stressing share contracts offer insurance and provide incentives for risk-averse agent to be diligent [7]; (2) transaction cost model, stressing the similar risk preference of principal and agent and focus on transaction-specific assets and especially enforcement costs [24]. 
A brief summary of the explanations for share contracts in existing empirical studies is presented in Table 1 as follows.

Table 1. The summary of the explanations for share contracts in empirical studies.

\begin{tabular}{|c|c|c|c|c|}
\hline Authors & Research Topic & $\begin{array}{l}\text { Support for } \\
\text { Risk-Sharing }\end{array}$ & $\begin{array}{c}\text { Support for } \\
\text { Transaction Cost }\end{array}$ & Other Explanation \\
\hline Hallagan (1978) & gold mining & & $\sqrt{ }$ & agricultural ladder [45] \\
\hline Mulherin (1986) & natural gas & & $\sqrt{ }$ & {$[46]$} \\
\hline Leffler and Rucker (1991) & timber sales & & $\sqrt{ }$ & [47] \\
\hline Ostuka et al. (1992) & farmland & $\sqrt{ }$ & $\sqrt{ }$ & legal land tenancy [22] \\
\hline Allen and Lueck $(1992,1995,1999)$ & farmland & & $\sqrt{ }$ & - \\
\hline Ackerberg and Botticini (2000) & farmland & & $\sqrt{ }$ & imperfect capital market \\
\hline Botticini and Kauffman (2000) & farmland & - & - & household structure [48] \\
\hline Ackerberg and Botticini (2002) & farmland & $\sqrt{ }$ & & - \\
\hline Zhao and Tang (2008) & farmland & - & - & off-farm employment [49] \\
\hline Gebregziabher and Holden (2011) & farmland & $\sqrt{ }$ & & $\begin{array}{l}\text { income and female } \\
\text { landlord households [50] }\end{array}$ \\
\hline Delpierre et al. (2014) & $\begin{array}{l}\text { insurance } \\
\text { agreements }\end{array}$ & & $\sqrt{ }$ & household wealth [51] \\
\hline
\end{tabular}

Note: The original table with part of the literature was from Allen and Lueck (1995). The author added other literature after 1995 to make a supplement.

The contract is designed to completely or partially transfer the property rights in order to unite the production of owners with different resources. Contract arrangements vary according to the difference in transaction costs, natural risk and legal system [43]. If transaction costs are zero, it does not matter who holds the ownership or residual rights to the physical asset consisting of the firms. Contract arrangements of microscopic organizations aim at minimizing the costs of ex ante covenanting and ex post supervising [44]. Facing a new profitable opportunity, the contracting parties will re-negotiate against the contract terms [52], thereby, the ex-ante relational contract might not continue because of the ex post internal or external changes in the structure of the contract [53]. As a result, vertical integration [12] and relational contracts [11] are both the optimal choice for the minimization of transaction costs. Under the condition of partially ex post contractible, the optimal contract arrangement is the trade-off of contract rigidity and flexibility, thus, the balance of freedom in adjustment afterward and the resulting reduction of performance [27].

\subsubsection{The Model}

Considering the dichotomous arrangement of fixed-rent contracts and share contracts, this article will proceed by the logit-regression analysis. Each sample is a single farmland transfer contract. The dependent variable is denoted as 1 if a contract is a share contract and 0 if fixed-rent. To examine exactly the factors underlying the contract framework of a balanced allocation of residual control and risk sharing, a regression analysis is adopted as follows:

$$
\mathrm{Y}=\operatorname{logit}\left(p_{i}\right)=\ln \left(\frac{p_{i}}{1-p_{i}}\right)=x_{i}^{\prime} \boldsymbol{\beta}+\varepsilon
$$

where $\mathrm{Y}$ is fixed-rent contract and share contract. The dependent variable is 1 if the contract is a share contract; otherwise, 0 if it is fixed-rent. $x$ is the vector of independent variables, and $\beta$ is the vector of parameters to be estimated.

Contract choice is affected by factor endowments, individual differences and the structure of the information [54]. The choice between fixed-rent and share contracts has been concerned by economists for decades. Theoretical works proceed to solve the problem of optimal contract form by examining the implication of various factors [31]. Risk allocation in contracts is influenced by information asymmetry 
and incompleteness $[55,56]$. A widely accepted explanation for the existence of share contracts in agriculture is that it serves as an inefficient but useful compromise to share risk at the expense of increasing transaction cost [57]. With the common application of wealth as the indicator of risk aversion, the potential problem of endogenous matching was often neglected in empirical research, which would lead to the deviation of the regression coefficient [7].

The matching of the residual rights allocation and the asset-specific investment had provided rationality to the effectiveness of the mixed ownership economy in China [58]. Changes in residual rights arrangements will bring the changes of costs and benefits; and ultimately affect the relationship-specific investment [36]. Besides the property rights arrangement, particularly noteworthy is that the contract of farmland transfer has differentiation with the standard landlord-tenant contract, such as the diversity of converted party and converted way, the similarity of the social-economic characteristics between the contract parties, and the interaction of pay method (cash or crop) with the contract arrangement (fixed or share). These observations pose interrelated questions about the specific determinants of contract framework for farmland transfer in China. Who will own the residual rights of control over the physical assets? By examining the contract options and its determinants, we focus on the bilateral relationship between two parties of the farmer and the actual farmland operator.

\subsection{The Data}

To examine the underlying determinants of contract options for farmland transfer, field surveyed data were used in this article from a survey conducted in Chengde city in China in July to November 2015. Chengde is located in the northeast of the Hebei province in north China, with a total area of 39,500 square kilometers. By 2014, Chengde had 11 subordinate counties with a total population of 3.7 million thousand, $79.8 \%$ of which is rural population. In recent years, on the basis of promoting farmland right registration and confirmation, the number of farmland transfer transactions and transferred scales have been increasing steadily. Of the total 4.4 million mu of farmland in Chengde city, 833.481 thousand mu had been transferred by 2014, involving 130 thousand farmer households.

The sampling strategy was as follows. Firstly, based on the scale of the farmland transfer at the county level, 5 of 11 counties were selected by using the systematic sampling method. A multistage random sampling technique was then employed to locate the towns, then the villages, and then the farmer households. Finally, 375 farmer households of 75 villages were randomly selected. For each randomly selected household, detailed information on the household-, plot- and contract-level were gathered.

Table 2 is a sum of selected contract indicators at plot level and contract level. In total, 1134 plots had been leased in or out. Except for the 142 plots leased without any payment, 992 plots were under contracts with rents, among which 686 plots were under shared rent, accounting for $60.49 \%$ of the total leased plots, and 306 were under fixed-rent rent, accounting for $26.98 \%$ of the leased plots. In the contract level, 353 of the total 405 contracts were with payment, among which 104 were share contracts, accounting for $17.54 \%$ of leased contracts, and 249 were fixed-rent contracts, accounting for $61.48 \%$ of leased contracts.

Given the demographic similarities between the leasing-out and leasing-in farmer households, it is plausible to treat both contract parties symmetrically [29]. Taken together, 686 plots were under 104 share contracts, and 306 plots were under 249 fixed-rent contracts. Although the majority of plots were under share contract, informing the perspective of contract types, only $17.54 \%$ of the total was under share contracts, less than half of that of fixed-rent contracts. This indicates that the share contract usually covers more plots than fixed-rent contracts. 
Table 2. The summary statistics of contract indicators in the plot level and contract level.

\begin{tabular}{lcclcc}
\hline \multicolumn{1}{c}{ Indicators } & Freq. & $\%$ & \multicolumn{1}{c}{ Indicators } & Freq. & $\%$ \\
\hline total plot under leasing contract & 1134 & 100 & total leasing contract & 405 & 100 \\
(1) plot under contract without rent & 142 & 12.52 & (1) contract without rent & 52 & 12.84 \\
(2) plot under contract with rent & 992 & 87.48 & (2) contract with rent & 353 & 87.16 \\
(1) plot under share contract & 686 & 60.49 & (1) share contract & 104 & 17.54 \\
(2) plot under fixed-rent contract & 306 & 26.98 & (2) fixed-rent contract & 249 & 61.48 \\
\hline
\end{tabular}

It is worth noting that there were 4 types of rent arrangements exhibited in our survey overall, namely, fixed-rent contracts, share contracts (pay a certain proportion of crop yields or cash income), joint-stock contracts, and contracts with a rent adjustment clause. The latter two types are essentially share contracts. The joint-stock contract is derived from the land joint-stock cooperation. All of the farmland was converted into a certain amount of stocks for the local cooperatives, and the cooperatives then leased large scaled farmland to the agricultural enterprises. These farmers could share the corresponding proportion of profits according to the farmland stocks they hold. As for the contract with the rent adjustment clause, Allen and Lueck (1989) verified that it is actually "a partial crop share contract" because these contracts have provisions to adjust the amount of cash rent due to the actual yields changes. The cash rent increases when the yield is unusually high. The contract parties' marginal share will change when the adjustment clause takes effect [29]. The summary statistics of contracts is shown in Table 3. In total, 104 of the total 353 leasing contracts were share contracts, among which 41 were proportional share contracts, 46 were joint-stock contracts, and 17 were contracts with an adjustment clause.

Table 3. The summary statistics of the contract frameworks.

\begin{tabular}{lcc}
\hline \multicolumn{1}{c}{ Contract Framework } & Freq. & \% \\
\hline Total leasing contract & 353 & 100 \\
(1) fixed-rent contract & 249 & 70.54 \\
(2) share contract & 104 & 29.46 \\
(1) proportional share contract & 41 & 11.61 \\
(2) joint-stock contract & 46 & 13.03 \\
(3) contract with an adjustment clause & 17 & 4.82 \\
\hline
\end{tabular}

Joint ownership of assets is optimal "by maximizing hold-up problems, minimizing the parties' payoffs if cooperation breaks down and therefore makes it easier to sustain cooperation" [36] (p. 67). In reality, a great deal of contractual incompleteness is undoubtedly linked to the inability of parties not only to contract very carefully about the future, but also to think very carefully about with an adjustment utility consequences of their actions. Perhaps the most direct incentive is to pay the agent based on with an adjustment measured performance in a given task or set of tasks. This is why the share contract was adopted. However, the percentage of a share contract is $29.46 \%$, lower than that of fixed-rent contracts because of costly monitoring. When an agent owns a set of productive assets, she maintains those assets more effectively. She also reaps the many implicit returns that are accrued through such an ownership. There is a conflict between incentive instruments and risk sharing [59].

\subsection{Variables}

Following the literature review, the meanings and units of independent variables are given in Table 4 . Brief summary statistics of variables by the dichotomy of fixed-rent contracts and share contract are made to make a prospective study of their effect on the contract framework. The implication of risk sharing and enforcement cost stressed in previous studies will be examined empirically in the following regression analysis. 
As a summary, variables employed in our regression analysis are as follows: right confirmation, crop types, scale ratio, risk attitude, long-lived asset inputs, labor inputs, intermediate input, contract duration, contract party, conversion way, non-agricultural income proportion, and household wealth.

Table 4. The definitions and units of independent variables.

\begin{tabular}{|c|c|c|c|c|c|c|c|}
\hline \multirow{2}{*}{ Variables } & \multirow{2}{*}{ Definition } & \multicolumn{2}{|c|}{ Total Sample } & \multicolumn{2}{|c|}{ Fixed Rent } & \multicolumn{2}{|c|}{ Share } \\
\hline & & Mean & Std. & Mean & Std. & Mean & Std. \\
\hline $\begin{array}{l}\text { Right } \\
\text { confirmation }\end{array}$ & $\begin{array}{l}=1 \text { if the contract right of farmland has } \\
\text { been registered; otherwise } 0 .\end{array}$ & 0.646 & 0.479 & 0.502 & 0.501 & 0.990 & 0.098 \\
\hline Risk attitude & householder's risk attitude scores & 4.830 & 1.301 & 4.727 & 1.364 & 5.077 & 1.103 \\
\hline Crop types & $\begin{array}{l}=1 \text { if there are field crops on the } \\
\text { converted farmland } \\
=0 \text { if there are cash crops }\end{array}$ & 0.448 & 0.498 & 0.297 & 0.458 & 0.808 & 0.396 \\
\hline Scale ratio & $\begin{array}{l}\text { The ratio of scale of converted farmland to } \\
\text { contracted farmland }{ }^{1}\end{array}$ & 0.547 & 0.812 & 0.431 & 0.827 & 0.826 & 0.706 \\
\hline Contract form & $\begin{array}{l}=1 \text { if the contract is formally written } \\
=0 \text { if the contract is orally specified }\end{array}$ & 0.796 & 0.404 & 0.904 & 0.296 & 0.538 & 0.501 \\
\hline $\begin{array}{l}\text { Long-lived assets } \\
\text { inputs }\end{array}$ & $\begin{array}{l}\text { the sum of household agricultural } \\
\text { machine and livestock value and hiring } \\
\text { machine cost (thousands of yuan) }{ }^{2}\end{array}$ & 2.445 & 11.722 & 2.924 & 13.742 & 1.298 & 3.611 \\
\hline $\begin{array}{l}\text { Proportion of } \\
\text { employed laborers }\end{array}$ & $\begin{array}{l}\text { the proportion of employed labor to the } \\
\text { total labor input }(\%)\end{array}$ & 0.078 & 0.206 & 0.088 & 0.211 & 0.052 & 0.192 \\
\hline $\begin{array}{l}\text { Intermediate } \\
\text { input }\end{array}$ & $\begin{array}{l}\text { the cost of seeds, pesticides, } \\
\text { and chemicals (yuan) }\end{array}$ & 5.383 & 54.404 & 6.949 & 64.742 & 1.633 & 1.616 \\
\hline Contract duration & $\begin{array}{l}=1 \text { if the farmland transfer contract has } \\
\text { explicitly stipulated duration }\end{array}$ & 0.601 & 0.49 & 0.639 & 0.481 & 0.510 & 0.502 \\
\hline Contract party & $\begin{array}{l}=1 \text { if the party of the converted farmland } \\
\text { is a small farmer household }{ }^{3} \\
=0 \text { if other parties }\end{array}$ & 0.632 & 0.483 & 0.683 & 0.466 & 0.510 & 0.502 \\
\hline Conversion way & $\begin{array}{l}=1 \text { if the farmland transfer is in an } \\
\text { organized way } \\
=0 \text { if in the spontaneous way } 4\end{array}$ & 0.385 & 0.487 & 0.297 & 0.458 & 0.596 & 0.493 \\
\hline Pay method & $\begin{array}{l}=1 \text { if the rent is paid by cash } \\
=0 \text { if by cultivated crop }\end{array}$ & 0.873 & 0.334 & 0.984 & 0.126 & 0.606 & 0.491 \\
\hline $\begin{array}{l}\text { Non-agricultural } \\
\text { income proportion }\end{array}$ & $\begin{array}{l}\text { the ratio of household wage income to } \\
\text { total income }(\%)\end{array}$ & 0.644 & 0.264 & 0.650 & 0.253 & 0.629 & 0.289 \\
\hline Household wealth & $\begin{array}{l}\text { the total value of household fixed assets } \\
\text { (thousand yuan) }{ }^{5}\end{array}$ & 22.405 & 34.943 & 26.051 & 39.336 & 13.676 & 18.392 \\
\hline
\end{tabular}

\footnotetext{
${ }^{1}$ Contracted farmland is the household farmland contracted by the village collective, converted farmland is the farmland leasing in or out. ${ }^{2}$ Long-lived assets inputs include agricultural machines such as tractors, seeding machines, pumps, threshing machines, harvesters, and livestock such as cattle, horses, donkeys and mules, and other agricultural machinery, implements and equipment used for agricultural production, and the cost of hiring other machines. ${ }^{3}$ Other parties include large-scaled operated farmer households (with more than $30 \mathrm{mu}$ of farmland due to the regulation of FAO), cooperation and agricultural enterprises. ${ }^{4}$ The organized way means the farmland transfer is organized by village collectives, cooperation, or agricultural enterprises and involved in a number of farmer households, and the spontaneous way means the leasing trade is generated between independent farmer households. ${ }^{5}$ Household wealth is measured by the total value of durable consumer goods like automobiles, motorcycles, other vehicles for daily use, TV sets, refrigerators, washing machines and computers.
}

\section{(1) Confirmation of farmland property rights}

Clarity of property rights is the precondition for transactions [60]. Allocation of property rights could internalize externalities [61]. The contract realizes the joint production by different resource owners through the partial or full transfer of property rights, and leads to different contractual arrangements due to transaction costs, natural risks, and legal arrangements [43]. Under the precondition of the land collective ownership, the farmland system of household contract responsibility had been implemented in China in 1980s. That is, farmland ownership belongs to the village collective, while the farmers only contract with the collective on certain plots and have farmland usufruct. 
Farmland rights of farmers are actually the control rights under such farmland systems [62]. Farmland transfer is essentially the transfer of farmland management rights through subcontracting, leasing, exchanging, and joint cooperation. The ambiguity of farmland rights has been puzzling researchers and policymakers for decades, especially its negative effect on farmland transfer [62].

The issue of farmland rights registration was initially introduced in the 1990s in China, but gradually implemented nationwide after 2008. The aim of the registration policy for farmlands is to strengthen the farmer's usufruct and ensure farmers' rights to possess, to utilize, and to seek profits from the farmland. In practice, it measures the plots' boundary and defines its location and scale, and further refines farmland contracts, makes a unified register book and gives farmers the certificate of farmland rights. In our empirical examination, the variable of confirmation of farmland rights is 1 if the farmer household's farmland had been registered, 0 if not.

(2) Risk sharing

In the fixed-rent contract, the party who operates the farmland is the complete residual claimant of the output, whereas, in a share contract, the risk is shared by the two sides [57]. To examine the risk-sharing hypothesis, two variables of householder's risk attitude and crop types on the converted farmland are involved in the regression.

Risk attitude is hypothetically treated as an important determinant of contract arrangement in the risk-sharing model. Three methods were mainly used to measure the individual's risk attitude. The first is based on the experimental method; the second is based on the implicit testing questions designed in the questionnaire survey; the third is indirectly using the household wealth as a proxy [7]. This article adopted the third method, not only because of the lack of the physical condition for experiments in our field survey, but also the difficulty for the local farmers to understand the experimental progress based on computer programs. Three testing questions and alternative answers were designed in our questionnaire (see Table 5). Farmers gave their answers in the interview and got the corresponding scores, and the total score of the three questions represented the level they prefer risk. The higher the total score, the more the farmer preferred risk.

Table 5. The testing questions for measuring the risk attitude in the questionnaire.

\begin{tabular}{llll}
\hline \multicolumn{1}{c}{ Questions } & \multicolumn{1}{c}{ Alternative Answers and Scores } \\
\cline { 2 - 4 } & \multicolumn{1}{c}{ 1 Score } & \multicolumn{1}{c}{ 2 Scores } & 3 Score \\
\hline $\begin{array}{l}\text { Suppose you can win a bonus } \\
\text { from a gambling game through } \\
\text { one of the following alternative } \\
\text { winning ways, which one you } \\
\text { would like to choose? }\end{array}$ & Get 1000 yuan directly & $\begin{array}{l}50 \% \text { chance of getting } \\
2000 \text { yuan, } 50 \% \text { chance } \\
\text { of getting no money }\end{array}$ & $\begin{array}{l}5 \% \text { chance of getting } \\
20,000 \text { yuan, } 95 \% \text { chance } \\
\text { of getting no money }\end{array}$ \\
\hline $\begin{array}{l}\text { Suppose you will lose a sum of } \\
\text { money from a gambling game } \\
\text { through one of the following } \\
\text { alternative ways, which one you } \\
\text { would like to choose? }\end{array}$ & Lose 1000 yuan directly & $\begin{array}{l}50 \% \text { chance of losing } \\
2000 \text { yuan, } 50 \% \text { chance } \\
\text { of losing no money }\end{array}$ & $\begin{array}{l}5 \% \text { chance of losing } \\
20,000 \text { yuan, } 95 \% \text { chance } \\
\text { of losing no money }\end{array}$ \\
\hline $\begin{array}{l}\text { When a new agricultural } \\
\text { technology (such as transgenic } \\
\text { technology) is launched if } \\
\text { there is no other restriction such } \\
\text { as funds, how would you adopt } \\
\text { the technology? }\end{array}$ & $\begin{array}{l}\text { For insurance purposes, } \\
\text { neither adopting it nor } \\
\text { not adopting it when } \\
\text { I have no other choice }\end{array}$ & $\begin{array}{l}\text { Wait and see the other's } \\
\text { effect of adoption }\end{array}$ & Take the lead in adopting \\
\hline
\end{tabular}

Crop types represent the natural risk. Cheung's risk-based hypothesis that sharecropping is more likely to be used with the crops with higher variable yields (that is, with more risk) is often used to rationalized share contracts [29]. The crop types are designated as 1 if it is a kind of grain crop and 0 if it is a cash crop. In our survey, the cash crops include vegetables, edible fungi, and flowers. According to the local statistic data, it can be considered that these cash crops have higher variable yields, that is, 
they are riskier than grain crops. The assignment is consistent with Rao (1971) who designated tobacco as a riskier crop in comparison with rice.

(3) Enforcement cost

As mentioned in the literature review, the evaluating cost of resource variability and the division cost of the output are the key elements for explaining the contract [29,63]. Scale ratio and contract form are used to explain the effect of enforcement cost on the contract framework.

Scale ratio is the proportion of converted area to the contracted farmland area. It is difficult to monitor the agricultural productive behavior and farmland fertility on large-scale converted farmland. The larger the scale ratio, the greater the premium should be placed on supervision. Therefore, farmers tend to accept share contracts.

The difference in contract form means the difference in the cost of dividing the output. When deciding the share proportion or rent adjustment clause in a formal written contract, the contract parties often spend a great time in ex ante calculation and negotiation. While in an oral contract the process is relatively simple, where share proportion is often orally decided after the harvest for convenience. Therefore, for the sake of the saving of enforcement cost, the fixed rent may be more likely to emerge in the formal contracts, and oral contracts are more likely to be with shared rent.

(4) Agricultural productive behavior

Both fixed-rent and share contracts are essentially the methods of coordinating the resources of different kinds of farmers [29]. How to use the converted farmland and allocate other variable input makes sense in explaining the contract framework. Agricultural input factors include intermediate inputs of seeds, pesticides, and fertilizers; labor inputs; and agricultural machinery. Among them, agricultural machinery consists of family-owned machinery and employed machinery.

For farmers leasing farmland out, the specific assets and variable inputs in agriculture represent their dependence on agricultural income, which may promote them to ask for fixed rents to avoid natural risks and market risks. For the farmers who leasing in, they pay a fixed annual rent and become the total residual claimants. There are incentives for the current production of over-utilizing the converted farmland to increase the output under fixed-rent contract. For example, farmers can increase the agricultural income by employing additional machinery and overusing chemicals and fertilizers that erode the soil. To explain the effect of machinery input on contract framework is also in line with the transaction model that stresses transaction-specific assets owned by different contract parties will impact the contract arrangement.

The control variables include contract duration, conversion party, conversion way, payment method, non-agricultural income proportion, household wealth, and risk attitudes.

Some preliminary findings are presented from the gaps in the summary statistics (see Table 4). The plots had not been registered and with cash crops on, it was more likely under fixed-rent contracts; formal contracts with explicitly stipulated duration and paid by cash were the most present along with fixed rent; spontaneous conversions between small farmers were more likely under fixed-rent contracts. Considering the household characteristics, the more input in agricultural machinery and intermediate input like seeds, fertilizers, and pesticides, the more likely the fixed rent would be adopted. Households with more wealth preferred fixed-rent contracts. In contrast, shared rent often appeared in formal contracts paid by crops. The larger the scale ratio was, the more likely a share contract would be adopted.

With no obvious group difference performed in other variables, the inferences derived from the summary statistics are limited. An explicit explanation of the contract framework for farmland transfer requires the analysis of the regression results with data on individual contracts. 


\section{The Regression Results and Analysis}

The results of logit regression are shown in Table 6. The overall fitness of the model is guaranteed (Prob $>$ chi2 $=0.000$ ) and the heteroscedasticity robust adjusted SD is employed. The result of the logit hereby is proved to be stable and effective.

Table 6. The results of the logit regression.

\begin{tabular}{|c|c|c|}
\hline Variables & Coefficients & Std. Err \\
\hline Right confirmation & $3.988^{* *}$ & $(2.031)$ \\
\hline Risk attitude 1 & 0.033 & $(0.209)$ \\
\hline Crop types & $1.213^{* * *}$ & $(0.398)$ \\
\hline Scale ratio & $0.822 * * *$ & $(0.274)$ \\
\hline Contract form & $-3.133^{* * *}$ & $(1.084)$ \\
\hline Long-lived assets inputs & $-0.120 *$ & $(0.062)$ \\
\hline Intermediate input & -0.046 & $(0.096)$ \\
\hline Contract duration & $3.167^{* * *}$ & $(0.472)$ \\
\hline Contract party & -0.678 & $(0.738)$ \\
\hline Conversion way & $1.552 * *$ & $(0.763)$ \\
\hline Payment method & $-3.463 * * *$ & $(0.780)$ \\
\hline Non-agricultural income proportion & -0.261 & $(0.695)$ \\
\hline Household wealth & -0.006 & $(0.007)$ \\
\hline Proportion of employed laborers & -1.591 & (1.267) \\
\hline Constant & -2.127 & (2.326) \\
\hline $\mathrm{N}$ & \multicolumn{2}{|c|}{353} \\
\hline Prob > chi 2 & \multicolumn{2}{|c|}{0.000} \\
\hline Pseudo R2 & \multicolumn{2}{|c|}{0.598} \\
\hline
\end{tabular}

Note: The risk attitude score in the regression is standardized. ${ }^{* * *}, * *$ and ${ }^{*}$ Denotes statistical significance at the $1 \%$, $5 \%$ and $10 \%$ level respectively. The numbers in bracket are heteroscedasticity robust adjusted SD.

\subsection{Right Confirmation and Contract Options}

In China, the farmland users are the full residual claimants due to the deliberate institutional ambiguity of the farmland property system in China [64]. Under the household contract responsibility system, farmers were given the residual rights of farmland use and usufruct [65]. However, government intervention on rights allocation by frequent farmland adjustments has led to incomplete farmland property rights and damaged farmers' long-term intentions of investment in farmlands [66]. It is claimed that the registration and confirmation of farmland rights will improve the rights stability and stimulate farmer households' willingness to increase intermediate inputs [67] and promote farmers to transfer farmland out [68]. Our calculation also shows the evidence that there are increases both in the long-lived assets inputs and intermediate inputs after farmland rights registration (see Table 7).

Table 7. The long-lived assets input and intermediate input before and after registration (thousand yuan).

\begin{tabular}{cccc}
\hline \multirow{2}{*}{ Variables } & Before Registration & After Registration & In Total \\
\cline { 2 - 4 } & Mean & Mean & Mean \\
\hline Long-lived assets inputs & 0.665 & 3.420 & 2.445 \\
Intermediate inputs & 3.548 & 6.389 & 5.383 \\
\hline
\end{tabular}

Farmland right confirmation has enhanced the likelihood of share contract in China because "sharecropping would dominate when markets are either absent or underdeveloped and the class structure is polarized" [24] (p. 360). The registration of farmland property rights simultaneously stabilizes farmers' farmland contract rights and allows the flexible conversion of farmland management rights, which clarify the various capacities, especially the usufruct [69]. After the registration, farmer households with the clarified usufruct are inclined to share the revenue from farmland management 
rather than a fixed rent for security. The exploitation of the farmland value as an asset makes it possible for a farmer household to be a residual claimant in farmland transfer.

\subsection{Crop Types and Contract Options}

The dominant contractual form varies with the crop and prevailing technology [24]. The low-risk crops are more likely to use share contract in our study [28]. The transaction cost model maintains that share contract was optimal being the trade-off between providing incentives for tenants in the current production and preventing the abuse of valuable assets provided by the landlord such as agricultural implements, livestock, and soil fertility [6]. Hence, share contracts are adopted to curb farmers' intention to exploit soil or other assets supplied by the landowner [29].

It has been verified that the share contract is strongly related with highly labor-intensive crops, larger number of hours of labor input [24], and larger scale of renting farmland [6]. The pursuit of maximizing current output could potentially damage valuable assets and soil fertility on the farm [6]. Given the incomplete insurance market, share contract theoretically functions to spread risks embedded in risky crops, while existing empirical studies have reported conflict results with this story [45]. Consisting with empirical studies by Allen and Lueck (1992) and Hllagan (1978), our result shows that share contracts are more likely to be employed on the less risky crops, as that which happened in India, the less risk rice was under a share contract, whereas the more risk tobacco was mostly under a fixed rent contract [70].

\subsection{Scale Ratio and Contract Options}

The effect of scale ratio is as expected. This finding fits the enforcement cost model stressing that the larger the ratio of converted farmland to contracted farmland is, the more likely the share contract will be used to avoid the moral hazard to abuse long-lived assets, in this case, the fertility of converted farmland. Contracts become more complex because of the uncertainties in transaction, asset specificity, and difficulty in measuring the transaction costs. Due to contract incompleteness, the property rights cannot be simply defined as ownership rights or decisional rights. There are costs at the contract execution stage, even if the contract has ex ante prescribed the obligations of farmers and managers.

\subsection{Contract Form and Contract Options}

The positive and significant coefficient of contract form also verified the effect of enforcement costs on contract arrangement. In practice, a written contract is more detailed in regulating terms of the pay method, contract duration, and pay method [71]. It is in line with the enforcement model that a higher measuring and calculating cost in formal written contact will leads to the fixed rent. Contracts could be divided into written and implicitly oral contracts in terms of the compliance mechanism. An explicit contract is a formal written contract that can be verified and enforced by third parties. On the contrary, an implicit oral contract is unobserved and unverifiable and takes reputation and trust as the guarantee for enforcement [72]. As the institutional environment where the transactions are carried out, the governance structure varies with the transaction characteristics [73]. The oral contract is more likely to be along with shared rent. Contrary to the coerciveness and transparency of third-party enforcement, self-enforcement of orally specified contracts is a mode of relational governance, which comes into effect through punishing the defaulter by terminating the transaction relationship to cause their loss of specific investments, or by transferring their credit information so that their reputation on the market is devalued [74]. Self-enforcement of a contract has lower costs in maintaining the order of transactions [75], which derives from saving the cost of specifying relevant contract terms, and reducing the time lag and noise in court enforcement [76]. That is why most contracts are enforced by the termination of business relations rather than through the power of the court.

Regarding the present value of future profits as the returns of reputation capital, whether the contracting parties will comply depends on their comparison of the short-term gains from defaulting and the present value of future loss from terminating the contract [74]. Despite the 
advantages of lower costs, the self-enforcement of contracts is limited by the shortage of reputation capital [77]. Accumulation of reputation capital is restricted in time and space by a natural lifetime, wealth accumulation, and reputation effects. The technical characteristics of transactions and the relationship between the contracting parties play important roles in determining the arrangements of the contract [78].

\subsection{The Long-Lived Assets Input and Contract Options}

For the leasing-in subjects, the input of long-lived assets and labor in agricultural production leads to the improvement of productivity and increase of yields, thus they are inclined to pay a fixed rent and to be the total residual claimants. In many regions, such as those surveyed by the author in northeast China, farmer households hold sizable grain stocks and devote much farmland and labor to grain cultivation despite the inferior asset and production return of grain. A highly specific investment requires a strong continuity of a transaction relationship. The transaction cost could be saved through the matching of transaction characteristics and governance structure [73].

Asset specificity, to a large extent, is the key determinant in the choice of governance structures. Transaction cost economics argues that parties make large relationship-specific investments which, in turn, results in the problem of "lock-in" [79]. The long-lived assets inputs, including the value of specific assets, livestock, and cost for hire machine, consistently significantly increases the likelihood of fixed-rent contracts. Eswaran and Kotwal (1985) suggested that "agricultural production entails the use of certain un-marketed resources, and access to these resources is obtained by marking their owners' residual claimants" (pp. 353-354). According to Grossman and Hart (1995), if certain contingent contracts cannot be made, then the second-best arrangement between two relationship-specific firms might well be one where the residual rights associated with capital ownership are concentrated in one hand (Grossman and Hart, 1995). This conclusion departs from the standard presumption, due to Grossman and Hart (1986) and Hart and Moore (1990), that the ownership of an asset depends on the relative importance of the investment of the parties involved [23,31].

As information becomes imperfect and costly, management by others replaces self-management through the advantage of specialized knowledge. The arrangement of residual control rights has notable impacts on the future revenue of the contracting parties [36]. If firms can be considered to be made up of owned and controlled property, the ownership rights to property will affect the distribution of ex post surplus and then affect the ex-ante investment decisions [31]. Aghion and Tirole (1992) make a distinction between real authority and formal (legal) authority; they argue that someone with superior information may have the effective power as those with the legal power, that is, owners, may follow his suggestions [80]. The combination of durable specific investments, future uncertainty, and cost realization emerge to be the key elements in understanding contract choice and design [81]. Holmstrom and Milgrom (1995) argued that, even if there is no specific investment, agents should own the assets when they (1) are not definitely risk-averse agents; (2) have a low variance of assets returns; and (3) have a low variance of measurement error of agent's performance in other aspects. Measurement cost is an important determinant of integration. Hence, asset ownership is often a broader, more powerful incentive instrument. When an agent owns a set of productive assets, she maintains those assets more effectively. She also reaps the many implicit returns that are accrued through such ownership. There is a conflict between incentive instrument and risk sharing. We want to emphasize that residual control rights are substitutes for performance incentives and extensively used when it is hard to assess the performance of the agent. Especially when it is difficult to measure the quality and quantity of production, "it may be optimal to provide no quantity incentives when quality is poorly measured" [82] (p. 28).

\subsection{Payment Method and Contract Options}

The payment method is a specific variable incorporated in our test contrasting with previous literature. The contract framework between the landlord and tenant in the west is usually the 
dichotomy of sharecropping (or "cropshare" in Allen and Lueck (1992)) and cash-rent, meaning the share contract is regularly paid by crops and the fixed-rent contract is paid by cash. This implies a priori difference in the cost of dividing output between the two types of contract. However, in our context of farmland transfer, both pay methods exists in the fixed-rent and share contracts (see the frequencies in contingency Table 8). It cannot be explained by output dividing cost as the previous literature does. A plausible explanation is farmers' perception of natural and market risk. The summary statistics of farmers' perception of natural and market risk is displayed in Table 9. It suggests that in farmers' perception of the risk brought by the fluctuation of crop yield is greater than the fluctuation of the market price. Therefore, in the contract paid by crops, farmers are more likely to make the agreement to share the yields with a certain proportion, so as to avoid the loss due to the extreme fluctuation of crop yields. When the contract is paid in cash, it means that the actual crop yield has been converted into money income, which is smoothed by the market price, whereby the influence of the fluctuation of crop yields could be reduced.

Table 8. The contingency table analysis by the payment method and contract arrangement.

\begin{tabular}{cccc}
\hline & Fixed-Rent Contract & Share Contract & In Total \\
\hline Paid by crop & 4 & 41 & 45 \\
Paid by cash & 245 & 63 & 308 \\
In total & 249 & 104 & 353 \\
\hline
\end{tabular}

Table 9. The farmers' perception of natural risk and market risk.

\begin{tabular}{clcc}
\hline Variables & \multicolumn{1}{c}{ Question in the Survey } & Mean & Std. \\
\hline Natural risk perception & $\begin{array}{l}\text { How much do you think the fluctuation of crop yield in } \\
\text { the converted farmland is? (=1 if no; }=4 \text { if very large) }\end{array}$ & 2.674 & 0.888 \\
\hline Market risk perception & $\begin{array}{l}\text { How much do you think the fluctuation of the crop price } \\
\text { in the converted farmland is? (=1 if no; =4 if very large) }\end{array}$ & 2.584 & 1.011 \\
\hline
\end{tabular}

Note: The data is from the two questions testing farmers' risk perception in the questionnaire of our survey.

\subsection{Contract Features and Contract Options}

There are still influences on contract arrangement from the other contract levels of variables. The result of contract duration is consistent with Laffont and Matoussi (1995) and Belleamare (2009), they suggest that contracts with an explicitly regulated duration are more likely to be along with shared rent. The explicitly regulated contract duration increases the stability of contract relationship, which is also a kind of property rights clarification. Farmers then have a more stable and clear expectation for future profits gains from the converted farmland, and they tend to get a share of the revenue. The duration of contracts is jointly affected by asset specificity, information asymmetry, transaction costs, risk aversion, and government intervention [83]. Long-term relations and benefit sharing mechanism could be strengthened by exact terms, like the regulated duration in formal contracts by avoiding transaction risks, reinforcing trust, and improving expectations for long-term cooperation [84].

The transferred farmland in an organized way is more likely to be under share contract. Farmland transfer in an organized way often involves one leasing-in organization, such as village collectives, cooperation, or agricultural enterprises, and more than one leasing-out farmers. By this way, the similarity in contracts with different farmer households reduce the enforcement cost of contracting, and the unified product measuring and calculating process also reduces the enforcement cost ex post. Meanwhile, these organizations should promise farmers the share of future revenue to persuade them leasing out their farmland in long term. The evidence is that the share contract signed with these organizations are usually with the upward rent adjustment clauses. 
In an institutional context, Bromely (1991) argues that property rights are social relationships amongst individuals within a society rather than a relationship between an individual and a particular object of value. The difficulty in observing and verifying the contracting parties' behavior leads to high enforcement costs [85]. Together with the other transaction costs of litigation and arbitration [86], it is extremely difficult for third-party enforcement, even in the process of solving the problem of "hold up", a new "hold up" will emerge [87]. The purpose of contract design is to save the cost in the process of contract designing, enforcement, and dispute arbitration. In the long history of political centralization and a relational society, there has been a complicated situation in China with the coexistence of traditional norms and market rules [88]. Blood and family relations in the unique diversity-orderly structure in China constitute the most stable social relationship [89], informal regulations of ethics, customs, and personal links, hence, play important roles in contract enforcement [90]. In the absence of formal regulations, informal regulations restrict the individual's behavior [91] and improve the efficiency of the contract by reducing the externality and uncertainty caused by the unspecified residual parts of the contracts [92]. Moreover, considering commitments, ethics, positive or negative incentives from group members, internalized informal codes of conduct can not only be the binding rules, but also be a personal habitual preference. Additionally, by a self-enforcing mechanism that relies on mutual trust, revenge or pressure of public opinion, regulations can restrict the behaviors of free riding and opportunism [93].

\subsection{Proportion of Employed Labors and Contract Options}

Since it is costly to monitor the quality and quantity devoted by agents, there are high opportunisms ex post. According to Williamson, bounded rationality and opportunism caused by limited knowledge, skill, foresight, time, and organizations are useful instruments for the achievement of knowledge. Klein (1980) claims two main reasons lead to the contract incompleteness, "First, uncertainty implies the existence of a large number of possible contingencies, and it may be extremely costly to know and specify in advance responses by the transacting parties to all of these possibilities. Second, contracts are incomplete because particular contractual performance, such as the level and the form of energy an employee is to devote to a complex task, may be prohibitively costly to measure and hence to specify contractually" [85] (p. 367). The increasing difficulty for monitoring tenants' work will lead to the preference over share contracts. As a potential source of increasing returns to scale, contract designing is to minimize the costs of ex-ante covenanting and ex post supervising [44].

When tenants' effort and diligence are difficult to monitor, there is an incentive for tenants under fixed-rent contracts to overproduce with overusing fertilizers and chemicals, or long-lived assets supplied by landowners. The choice between crop share and cash-rent contracts was summarized by Allen and Lueck (1989) as "the trade-off between input-distortion costs and output-division costs" (p. 402). The difficulty in observing and verifying the contracting parties' behavior leads to high enforcement costs [85]. It is costly to monitoring the quality and quantity devoted by agents. It is especially hard to measure the effort of daily operation and maintenance of the land user. So, there are high opportunisms ex post. Higher levels of human capital should increase the productivity of activities related to the marketing of goods and should facilitate the speed and accuracy of the information flows within the market. Allen and Lueck (1999) claimed that "share contracts are chosen when the margins for moral hazard are large and many" (pp. 448-449). For example, Eswaran and Kotwal (1985) suggested that intensive labor input needs great premium to place on supervision, which was the reason why sharecropping was prevalent in the south of the U.S. where highly-labor intensive crops were cultivated.

\subsection{Risk Attitudes and Contract Options}

Cheung (1983) claimed that workers' contributions could be measured and priced in piece-rate contracts. Risk attitudes of the contracting parties have been unable to effectively explain the choice of contract; instead, incentives and enforcing costs provide more evidence [28]. Taking into account 
of risk-sharing, contract arrangement depends on the contracting parties' attitude towards risk [94], the equilibrium contractual arrangement emerges from the optimized decision of both parties in a given environment [24].

Overall, our conclusion fails to support the typical risk-sharing model. It shows that there is no significant effect of a farmer householder's risk attitude on contract arrangement, the result is in line with the majority of empirical tests. It is also noteworthy that the canonical risk-sharing tenancy model implies a match between a rich risk-neutral landlord and a poor risk-averse tenant [57]. However, this assumption of the different demographics between landlord and farmer does not readily fit the situation of farmland transfer in rural China. The farmers being either party in farmland transfer are both risk-neutral because of the similarity of their demographics [28]. Table 10 exhibits the summary statistics of household demographics by contract party and T-test between groups. It is shown that, except for the householder's age and family size, there are no significant differences between the leasing-in and leasing-out parties. The agricultural production inputs of family labor, farmland, and long-lived assets are all especially similar (see rows 7-9 in Table 10). In contrast to the canonical risk-sharing tenancy model, even the leasing-in parties have higher scores of risk attitude (5.319 of the leasing in versus 4.711 of the leasing out, see the last row in Table 10), meaning to prefer risk more.

Wealth is mostly regarded as the proxy of risk attitude based on the assumption of declining absolute risk aversion, which stressed that the increase in wealth will lead to the preference of risk [28]. Similarly, the effect of household wealth is not significant in our result. Even the coefficient direction is different with risk attitudes, representing no support for the risk-sharing model.

Table 10. The summary statistics for the household demographics by contract party.

\begin{tabular}{llccc}
\hline \multirow{2}{*}{ Demographic Variables } & \multicolumn{1}{c}{ Definition and Unit } & Leasing-In & Leasing-Out & Total Sample \\
\cline { 2 - 5 } Householder's age & \multicolumn{1}{c}{ (years) } & Mean & Mean & Mean \\
\hline Householder's education & (years) & 47.333 & $51.442^{* * *}$ & 50.636 \\
\hline Total income & $\begin{array}{l}\text { Family annual total income } \\
\text { (thousand yuan) }\end{array}$ & 5.652 & 8.000 & 7.934 \\
\hline Household wealth & $\begin{array}{l}\text { Total value of household fixed } \\
\text { assets (thousand yuan) }\end{array}$ & 22.158 & 55.234 & 56.111 \\
\hline Family size & Number of family members & 3.522 & $3.827^{* *}$ & 3.768 \\
\hline Family labor size & Number of family labors & 2.971 & 2.954 & 2.958 \\
\hline Farmland scale & $\begin{array}{l}\text { Scale of household contracted } \\
\text { farmland (Mu) }\end{array}$ & 13.413 & 18.901 & 17.828 \\
\hline Long-lived assets inputs & $\begin{array}{l}\text { Sum of the household } \\
\text { agricultural machine and } \\
\text { livestock value and hiring } \\
\text { machine cost (thousand yuan) }\end{array}$ & 3.536 & 2.18 & 2.445 \\
\hline Risk attitude & \begin{tabular}{l} 
Householder's risk attitude scores \\
\multicolumn{1}{c}{ Note: }
\end{tabular} & 5.319 & 4.711 & 4.830 \\
\hline
\end{tabular}

Admittedly, our results are in line with most existing studies, which provide no significant evidence for the risk-sharing hypothesis in explaining contract framework because of the similarities of farmer households' demographics of either side of the farmland transfer, which lead to the similarity of their risk attitudes. Rather, the empirical results support the implication of enforcement costs exerted by the effects of the scale ratio and the contract form. That is, share contract will be used when the costs of dividing and measuring products are low, and to avoid the moral hazard to abuse long-lived assets. The effects of conversion way and crop types on contract options also verified this implication. More importantly, the results show significant evidence of the effect of farmland right confirmation on the distribution of residual control and risk sharing of farmland transfer in China. The registration policy promotes the exploitation of the farmland value as an asset through confirming and clarifying 
farmland property rights, which makes it possible for a farmer household to be a residual claimant in farmland transfer. Finally, our results provide little evidence of the effect of intermediate input, the identification of the conversion party, and non-agricultural income proportion.

\section{Discussion and Conclusions}

In this study, we test the major implications of farmland property rights, risk sharing, and enforcement cost on contract framework using detailed data on 353 individual farmland transfer contracts from Chengde city in the north China. The results thereby offer a systematic review of contract theory and aim to provide practice-oriented guidelines.

Our logit estimates show that the policy of farmland property rights registration has a significant effect on the contract framework, indicating the importance of the clarity of property rights for farmers participating in the agricultural revenue sharing. From the results of scale ratio, contract form, and conversion way, the approach of enforcement cost is verified to be a useful tool for understanding the contract arrangement for farmland transfer. The decrease in the enforcement cost through reducing the difficulty of supervision and the cost of writing and enforcing contract, such as the small-scale conversion, orally contracting, and organized conversion, will increase the likelihood of share contracts. At the same time, contract duration, conversion way, and household-level variables of long-lived asset inputs have a significant effect on the contract arrangement. The access to the un-marketed resources makes their owners residual claimants. However, our findings fail to support the implication of risk sharing as an explanation of contract framework for farmland transfer. Farmer householder's risk attitudes have no significant effect on contract arrangement, and the effect of crop types is opposite with the traditional theoretical hypothesis. Given the context of farmland transfer in China, one plausible explanation is the similarity between the contract parties' demographics. The examination of the symmetric position of farmer households as two contracted parties makes up for the existing literature, especially for the neglect of the underlying reason for the inapplicability of risk sharing theory.

Based on the vast existing literature, by analyzing the farmland property right system we tried to highlight the effect of farmland right confirmation on the contract framework for farmland transfer, which is essentially the right transfer. Focusing on the ongoing implementation of farmland rights registration policy in the study area makes it helpful for the comparative analysis of policy effectiveness. The main contribution of this article is to clarify the effect of the farmland rights confirmation on the contract framework with a balanced distribution of risk and control rights under the farmland system in China. Farmland rights confirmations provide significant explanations of contract options. It indicates that the rights confirmation reveals farmland property value attached to farmland rights. Farmers with the confirmed rights could be the residual claimants of farmland property value, and they are more likely to share the revenue, as well as risk, from farmland management. Under the share contract, the residual control rights are substituted for performance incentives, which should be associated with capital and assets ownership. The appropriate allocation of residual control rights makes it more efficient of contract design and choice in farmland transfer.

This article explains why share contracts and fixed-rent contracts were adopted. The government policy has an important role in promoting reasonable contract arrangement for farmland transfer to achieve a symmetric distribution of the residual rights and risk sharing through clarifying farmland rights and reduce enforcement cost. It is necessary to clarify the farmland property right to protect farmers' rights benefiting from the right transfer. The essence of China's farmland system change is a gradual process of giving farmers residual control rights and residual claims [95]. In the context of ambiguous farmland rights in China, farmland rights registration and confirmation is undoubtedly an effective measure to achieve a balanced distribution of risk and residual controls.

Author Contributions: H.H. conceptualized and designed the research, supervised the whole process, review and editing the manuscript; H.L. performed the research, did the data curation and wrote original draft. All authors have read and approved the final manuscript. 
Acknowledgments: This research was supported by the Major Program of the National Social Science Foundation of China (No. 14 ZDA070) and the Key Project of Natural Science of Zhejiang Province (LZ14G30001).

Conflicts of Interest: The authors declare no conflict of interest. The founding sponsors had no role in the design of the study; in the collection, analyses, or interpretation of data; in the writing of the manuscript, and in the decision to publish the results.

\section{References}

1. Olson, M. Logic of Collective Action Public Goods and the Theory of Groups. 1965. Available online: https:/ / moodle.drew.edu/2/pluginfile.php/225050/mod_resource/content/2/Olson\%20\%281967\%29\% 20Logic\%20of\%20Collective\%20Action\%20\%28book\%29.pdf (accessed on 31 May 2018).

2. Coase, R.H. The nature of the firm. Economica 1937, 4, 386-405. [CrossRef]

3. Fei, F.; Jiang, S. The Paradigm Evolution of Contract Theory; Salanie, B., Ed.; Shanghai University of Finance and Economics Press: Shanghai, China, 2008; pp. 1-12.

4. Sykuta, M.E.; Cook, M.L. A new institutional economics approach to contracts and cooperatives. Am. J. Agric. Econ. 2001, 83, 1273-1279. [CrossRef]

5. Cheung, S.N. The Theory of Share Tenancy; Arcadia Press Ltd.: Glenside, PA, USA, 1969.

6. Ackerberg, D.A.; Botticini, M. The Choice of Agrarian Contracts in Early Renaissance Tuscany: Risk Sharing, Moral Hazard, or Capital Market Imperfections? Explor. Econ. Hist. 2000, 37, 241-257. [CrossRef]

7. Ackerberg, D.A.; Botticini, M. Endogenous matching and the empirical determinants of contract form. J. Political Econ. 2002, 110, 564-591. [CrossRef]

8. $\mathrm{Fu}, \mathrm{C}$. The Governance Structure of the Rural Community Based Joint Stock Cooperative System-A Perspective of Transaction Cost Economics. Issues Agric. Econ. 2007, 17. [CrossRef]

9. Yang, M. The Evolution of Agricultural Industrialization Management Organization Form: A Theoretical Explanation Based on Endogenous Transaction Cost. Chin. Rural Econ. 2002, 18, 11-15.

10. Qian, Z. Saving Transaction Costs: Key to the Success of Agricultural Industrialization-A Case Study of Ruyi Group of Jiangsu. Chin. Rural Econ. 2000, 16, 62-66.

11. Cai, R.; Cai, S. "Company+Farmers” Mode: Risk Transfer System and Farmers' Contracting Choice. J. Nanjing Agric. Univ. Soc. Sci. Ed. 2013, 13, 19-25.

12. Liu, J.; Qi, C. The Study on the Factors Affecting Contract Choice in "Company and Peasant Household Mode": An Analytical Framework of Transaction Cost. Econ. Surv. 2009, 106-109. Available online: http:/ / en.cnki.com.cn/Article_en/CJFDTOTAL-JJJW200904031.htm (accessed on 31 May 2018).

13. Zhou, L.; Cao, L. Factor Contract is Superior to Commodity Contract. Econ. Res. J. 2002, 14-19. Available online: http:/ / en.cnki.com.cn/Article_en/CJFDTOTAL-JJYJ200201001.htm (accessed on 31 May 2018).

14. Nie, H. The Optimal Agricultural Contracts and the Models of Agricultural Industrialization in China. Chin. Econ. Quart. 2013, 313-330. Available online: http://en.cnki.com.cn/Article_en/CJFDTOTALJJXU201301016.htm (accessed on 31 May 2018).

15. Duan, W.; Yuan, S. Risk Sharing and Incentive Contract: Further Discussion on Principal-Agent Theory. Nankai Econ. Stud. 2004, 20, 19-25.

16. Jiang, X.; Heng, X. Study on the Formation Mechanism and Externality of Rural Land Circulation Risk. Rural Econ. 2011, 29, 27-30.

17. Li, Q. Exploration on the Practice of Rural Land Mortgage Mode and its Risk Prevention. J. Fujian Normal Univ. Philos. Soc. Sci. Ed. 2013, 58, 28-32.

18. Akerlof, G.A. The market for" lemons": Quality uncertainty and the market mechanism. Quart. J. Econ. 1970, 84, 488-500. [CrossRef]

19. Edgeworth, F.Y. Mathematical Psychics: An Essay on the Application of Mathematics to the Moral Sciences; CK Paul \& Co.: London, UK, 1881.

20. Arrow, K.J.; Debreu, G. Existence of an equilibrium for a competitive economy. Econ. J. Econ. Soc. 1954, 22, 265-290. [CrossRef]

21. Knight, F.H. Risk, Uncertainty and Profit; Hart, Schaffner and Marx: New York, NY, USA, 1921.

22. Otsuka, K.; Chuma, H.; Hayami, Y. Land and labor contracts in agrarian economies: Theories and facts. J. Econ. Lit. 1992, 30, 1965-2018.

23. Stiglitz, J.E. Incentives and risk sharing in sharecropping. Rev. Econ. Stud. 1974, 41, 219-255. [CrossRef] 
24. Eswaran, M.; Kotwal, A. A theory of contractual structure in agriculture. Am. Econ. Rev. 1985, 75, 352-367.

25. Da, F.; Zhang, W. The Meaning and Measurement of Transaction Cost: Review and Prospect. Res. Inst. Econ. 2010, 8, 225-241.

26. Huang, S. The Main Defects of Transaction Cost Theory. Stud. Explor. 1996, 18, 4-10.

27. Hart, O.; Moore, J. Contracts as reference points, National Bureau of Economic Research. Quart. J. Econ. 2008, 123, 1-48. [CrossRef]

28. Allen, D.W.; Lueck, D. The role of risk in contract choice. J. Law Econ. Organ. 1999, 15, 704-736. [CrossRef]

29. Allen, D.; Lueck, D. Contract Choice in Modern Agriculture: Cash Rent Versus Cropshare. J. Law Econ. 1992, 35, 397-426. [CrossRef]

30. Allen, D.W.; Lueck, D. Risk preferences and the economics of contracts. Am. Econ. Rev. 1995, 85, 447-451.

31. Grossman, S.J.; Hart, O.D. The costs and benefits of ownership: A theory of vertical and lateral integration. J. Political Econ. 1986, 94, 691-719. [CrossRef]

32. Bromley, D.W. Environment and Economy: Property Rights and Public Policy; Blackwell: Oxford, UK, 1991; p. 102.

33. Salanie, B. The Economics of Contracts: A Primer; MIT Press: Cambridge, MA, USA, 2005.

34. Brousseau, E.; Glachant, J.M. Contract Economics and the renewal of economics. In The Economics of Contracts: Theories and Applications; Cambridge University Press: Cambridge, UK, 2002.

35. Baker, G.; Gibbs, M.; Holmstrom, B. The internal economics of the firm: Evidence from personnel data. Quart. J. Econ. 1994, 109, 881-919. [CrossRef]

36. Hart, O. Firms, Contracts, and Financial Structure; Oxford University Press: Oxford, UK, 1995.

37. Arrow, K.J. The Economics of Agency; Harvard Business School Press: Boston, MA, USA, 1984.

38. Li, F. Contract Economics (Translator's Preface). In Contract Economics; Economic Science Press: Beijing, China, 1999.

39. Mirrlees, J.A. The optimal structure of incentives and authority within an organization. Bell J. Econ. 1976, 7, 105-131. [CrossRef]

40. Laffont, J.; Martimort, D. The Theory of Incentives: The Principal-Agent Model; Princeton University Press: Princeton, NJ, USA, 2009.

41. Azariadis, C. Implicit contracts and underemployment equilibria. J. Political Econ. 1975, 83, $1183-1202$. [CrossRef]

42. Cheung, S.N. Transaction Costs, Risk Aversion, and the Choice of Contractural Arrangements. In Property Rights and Institutional Change; Coase, R.H., Ed.; Shanghai Joint Publishing Corporation: Shanghai, China, 1994; pp. 137-165.

43. Cheung, S.N. The contractual nature of the firm. J. Law Econ. 1983, 26, 1-21.

44. Yang, R.; Zhou, Y. Transaction cost and the Choice of the Distribution Contract of Enterprise's Ownership. Econ. Res. J. 1998, 44, 30-39.

45. Hallagan, W. Self-Selection by Contractual Choice and the Theory of Sharecropping. Bell J. Econ. 1978, 9, 344-354. [CrossRef]

46. Mulherin, J.H. Complexity in Long-Term Contracts: An Analysis of Natural Gas Contractual Provisions. J. Law Econ. Organ. 1986, 2, 105-117.

47. Leffler, K.B.; Rucker, R.R. Transactions Costs and the Efficient Organization of Production: A Study of Timber-Harvesting Contracts. J. Political Econ. 1991, 99, 1060-1087. [CrossRef]

48. Botticini, M.; Kauffman, K.D. Do Woman Matter? Household Structure, Rsk and Contract Choice. 2000. Available online: http:/ / citeseerx.ist.psu.edu/viewdoc/summary?doi=10.1.1.199.4125 (accessed on 31 May 2018).

49. Zhao, Q.; Tang, Z. Farmland transfer and the contract choice: An empirical study in Mianzhu City in Sichuan Province. Chin. Rural Surv. 2008, 13-19.

50. Gebregziabher, G.; Holden, S.T. Distress rentals and the land rental market as a safety net: Contract choice evidence from Tigray, Ethiopia. Argic. Econ. 2011, 42, 45-60. [CrossRef]

51. Deininger, K.; Ali, D.A.; Alemu, T. Land Rental in Ethiopia: Marshallian Inefficiency or Factor Market Imperfections and Tenure Insecurity as Binding Constraints? 2010. Available online: http:/ / documents.banquemondiale.org/curated/fr/332521468030666454/Land-rental-in-EthiopiaMarshallian-inefficiency-or-factor-market-imperfections-and-tenure-insecurity-as-binding-constraints (accessed on 31 May 2018).

52. Hart, O.D. Incomplete Contracts and the Theory of the Firm. J. Law Econ. Organ. 1988, 4, 119-139. 
53. Zylbersztajn, D.; Lazzarini, S.G. On the survival of contracts: Assessing the stability of technology licensing agreements in the Brazilian seed industry. J. Econ. Behav. Organ. 2005, 56, 103-120. [CrossRef]

54. Luo, B.; He, Y. Game Equilibrium, Factor Characteristics, and Contractual Choice-An Inquiry into the Share Tenancy Theory. Econ. Res. J. 2015, 50, 162-174.

55. Huang, Z.; Wang, Y. Fairness Preference, Compensation Regulation and Incentives of Senior Managers in State-owned Enterprises-Based on Behavior Contract Theory. J. Financ. Econ. 2009, 16-27. Available online: http:/ / en.cnki.com.cn/Article_en/CJFDTOTAL-CJYJ200901004.htm (accessed on 31 May 2018).

56. Liu, F. Incomplete Contracts and the Barriers to Performance: A Case Study of Order Agriculture. Econ. Res. J. 2003, 22-30. Available online: http:/ / en.cnki.com.cn/Article_en/CJFDTOTAL-JJYJ200304002.htm (accessed on 31 May 2018).

57. Bellemare, M.F. Sharecropping, Insecure Land Rights and Land Titling Policies: A Case Study of Lac Alaotra, Madagascar. Dev. Policy Rev. 2009, 27, 87-106. [CrossRef]

58. Tang, J. An Analysis of Mixed Ownership Development in State-owned Enterprises: An Imperfect Contract Perspective. Chin. Ind. Econ. 2014, 32, 31-43.

59. Demsetz, H.; Lehn, K. The Structure of Corporate Ownership: Causes and Consequences. J. Political Econ. 1985, 93, 1155-1177. [CrossRef]

60. Coase, R.H. Problem of social cost. J. Law Econ. 1960, 3, 1-44. [CrossRef]

61. Demsetz, H. Toward a theory of property rights. Am. Econ. Rev. 1967, 57, 347-359.

62. Huang, L.; Tan, R. Is China's Farmland Property Right System is Intentionally Made Ambiguous? Chin. Rural Surv. 2014, 2-13.

63. Barzel, Y.; Suen, W. Moral hazard, Monitoring Cost, and the Choice of Contract. Nanjing Bus. Rev. 2005, 5, 23-38.

64. Ho, P. Institutions in Transition: Land Ownership, Property Rights and Social Conflict in China; Oxford University Press: Oxford, UK, 2005.

65. Yao, Y. China's Rural Land System: An Analytical Framework. Soc. Sci. Chin. 2000, 21, 54-65.

66. Zhu, X.; Chen, F. Theoretical Exploration on the Construction of Rural Property Rights System. Chin. Rural Econ. 1993, 9, 21-24.

67. Huang, J.; Ji, X. The Verification of the Right to Use Farmland and Farmers' Long-term Investment in Farmland. Manag. World 2012, 28, 76-81.

68. Ye, J.; Jiang, Y.; Prosterman, R.; Zhu, K.; Feng, L.; Li, P. Research on China's rural land use right in 2005: Survey results of 17 provinces and policy implications. Manag. World 2006, 22, 77-84.

69. Zhang, S.; Cheng, L. The Complexity of Property Rights and the Theory of Implementable Rights: An Explanation for the Evolution of Rural Land Property Rights in China. Chin. Econ. Quart. 2012, 1219-1238. Available online: http:/ / en.cnki.com.cn/Article_en/CJFDTOTAL-JJXU201204004.htm (accessed on 31 May 2018).

70. Rao, C.H.H. Uncertainty, Entrepreneurship, and Sharecropping in India. J. Political Econ. 1971, 79, 578-595.

71. Qiu, H.; Liu, L.; Li, D.; Zhang, C. Farm size, Tenure Security and Land Productivity: An Empirical Study based on Plot-level Survey Data from Four Provinces in China. Chin. Rural Econ. 2017, 30-43. Available online: http: / / en.cnki.com.cn/Article_en/CJFDTOTAL-ZNJJ201706003.htm (accessed on 31 May 2018).

72. Kreps, D.M.; Wilson, R. Reputation and imperfect information. J. Econ. Theory 1982, 27, 253-279. [CrossRef]

73. Williamson, O.E. Transaction-cost economics: The governance of contractual relations. J. Law Econ. 1979, 233-261. [CrossRef]

74. Telser, L.G. A theory of self-enforcing agreements. J. Bus. 1980, 53, 27-44. [CrossRef]

75. Macaulay, S. Non-contractual relations in business: A preliminary study. Am. Soc. Rev. 1963, $28,55-67$. [CrossRef]

76. Klein, B. The role of incomplete contracts in self-enforcing relationships. Rev. Déconomie Ind. 2000, 92, 67-80. [CrossRef]

77. Klein, B. The role of incomplete contracts in self-enforcing relationships. In The Economics of Contracts: Theories and Applications; Cambridge University Press: Cambridge, UK, 2002.

78. Dorward, A. The effects of transaction costs, power and risk on contractual arrangements: A conceptual framework for quantitative analysis. J. Agri. Econ. 2001, 52, 59-73. [CrossRef]

79. Williamson, O.E. The Economic Intstitutions of Capitalism; Simon and Schuster: New York, NY, USA, 1985. 
80. Aghion, P.; Bolton, P. An incomplete contracts approach to financial contracting. Rev. Econ. Stud. 1992, 59, 473-494. [CrossRef]

81. Joskow, P.L. Contract duration and relationship-specific investments: Empirical evidence from coal markets. Am. Econ. Rev. 1987, 77, 168-185.

82. Holmstrom, B.; Milgrom, P. Multitask principal-agent analyses: Incentive contracts, asset ownership, and job design. J. Law Econ. Organ. 1991, 7, 24-52. [CrossRef]

83. Wang, Y.; Fan, J. The Choice of Long-term Contract: Transaction or Relationship?-A Two-dimensional Analysis Framework Based on Asset Specificity. Soc. Sci. Heilongjiang 2014, 25, 69-72.

84. Ferguson, R.J.; Paulin, M.; Moslein, K.; Muller, C. Relational governance, communication and the performance of biotechnology partnerships. J. Small Bus. Enter. Dev. 2005, 12, 395-408. [CrossRef]

85. Klein, B. Transaction cost determinants of "unfair" contractual arrangements. Am. Econ. Rev. 1980, 70, 356-362.

86. Klein, B.; Crawford, R.G.; Alchian, A.A. Vertical integration, appropriable rents, and the competitive contracting process. J. Law Econ. 1978, 21, 297-326. [CrossRef]

87. Klein, B. Contracts and Incentives: The Role of Contract Terms in Ensuring Compliance. In The Economics of Contract (Theories and Application); Eric Brousseau, J.M.G., Salanie, B., Eds.; Renmin University Press: Beijing, China, 1999; pp. 184-211.

88. Xu, D.; Wang, G. Review of the Development of Contract Enforcement Theory. J. Anhui Univ. Technol. Soc. Sci. 2010, 27, 44-47.

89. Fei, X. The Fertility Regimes in Rural China; Peking University Press: Beijing, China, 1998.

90. Luo, B.; Liu, Q. Analysis of Land Circulation Disputes based on Contract: from Questionnaire of Farmers in Guangdong Province. Soc. Sci. Guangdong 2013, 30, 35-44.

91. Wang, D. General Theory of Institutional Innovation. Econ. Res. J. 1992, 38, 69-80.

92. Yang, L. The Contract Surplus, Residual Control Rights and Residual Claim Rights-Taking Shandong Rural Pear "Green" Procurement Contract as an Example. Econ. Rev. 2001, 22, $28-32$.

93. Pretty, J.; Ward, H. Social capital and the environment. World Dev. 2001, 29, 209-227. [CrossRef]

94. Borch, K. Equilibrium in a reinsurance market. In Foundations of Insurance Economics; Springer: Berlin, Germany, 1992; pp. 230-250.

95. He, Y.; Luo, B. Land Transfer, Transaction Costs and Property Rights Control: A Theoretical Model and Game Analysis. Rural Econ. 2012, 30, 7-12. 